\title{
The Impact of Home Background and Locality on the Secondary School Students' Academic Performance in Agriculture in Enugu State, Nigeria
}

\author{
Cajethan Uche Ugwuoke* Godwin Emeka Eze ${ }^{1}$, Benedicta Anene Omeje ${ }^{2}$
}

${ }^{*}, 2$ University of Nigeria, Nsukka

\section{A R T I C L E I N F 0 \\ Article history: \\ Received 20 July 2018 \\ Received in revised \\ form \\ 10 August 2018 \\ Accepted 15 October \\ 2018 \\ Available online 28}

November 2018

Keywords:

academic performance,

home background, urban

and rural localities,

teaching and learning

\begin{abstract}
A B S T R A C T
Home background and locality are two significant factors that affect the academic performance of students in agriculture. The home determines the comfort of the students for academic activities while locality provides a conducive environment for students to study. The study was aimed at determining the impact of home background and locality on the secondary school students' academic performance in agriculture. Survey research design was adopted. The study population was 14,750 where 1,616 respondents were selected. The sample size was made up of 624 teachers of agriculture and 992 students of agriculture from 291 secondary schools in the 17 local government areas of Enugu state, Nigeria. A structured questionnaire was used to collect data. Data collected were subjected to mean and t-test statistic to answer research questions and test the null hypotheses at 0.05 level of significance. Results show that there was the statistically significant difference in the impact of home background on the students' academic performance in agriculture. It provides the parents with insights on the needs to make the homes conducive for learning and provide the necessary environment that would promote their children's academic performance in agriculture..
\end{abstract}

\section{Introduction}

Home is the first socializing agent of a child. It comprises the father, mother, brothers, sisters and others living with them. The home is one of the agents that creates the first impression which lasts throughout a child's life and also seen as a place that shapes the child's attitude and behaviour towards career development (Amadi and Ani, 2017). Students come from different home backgrounds and therefore have different upbringing (Osuafor and Okonkwo, 2013). Students home background is a major factor influencing learning because different students background characteristics exert a strong influence on their academic performance (Kakumbi et al., 2016). According to Dzever (2015), there is a significant relationship between the three dimensions of parenting styles at home and the academic performance of secondary school students. It was further found that parental restrictions on child behaviour and parental involvement in their children education is higher among urban students than their rural counterparts (Doley, 2018).

This signifies that the academic performance of secondary school students can as well be influenced by urban and rural localities. According to Owoeye and Yara (2011), students in the urban locations have a very great advantage by learning in an urban environment, which apparently enriches their academic performance, despite the apparent disadvantage of having to learn in large classes. Students in urban environment enjoy amenities like electricity, television, computer, and other facilities that can facilitate learning. Such amenities are not available in rural environments. Students in the rural communities travel 
a long distance to reach schools and may not afford to hire transport particularly those from poor families (Mhiliwa, 2015). After such a long travel to school, the students may not have enough energy to participate actively in academic activities. It was reported that most remote communities in developing countries do not have schools due to poor road network linking the communities (Olamiju and Olujimi, 2011). Poor infrastructural facilities in some localities may affect the academic performance of secondary school agricultural science students.

Agricultural science is a body of knowledge that deals with the production of crops and rearing of animals for food, income, animal feed, raw materials, among others. Agricultural science according to Egbule (2002) is the science of production, storage, distribution and marketing of plants, animals, or other products. Agricultural science as a vocational subject is referred to as that aspect of the educational process involving, in addition to general education, the study of technologies and related sciences and the acquisition of practical skills, attitudes, understanding and knowledge relating to plant and animal production for economic and social life (Federal Republic of Nigeria, 2014). The programme is designed to equip the students with the requisite knowledge and skills that will help them live independent lives. The students that study agricultural science in secondary schools are expected to be gainfully employed, establish an agricultural enterprise or join further education.

Unfortunately, some graduates of secondary school agricultural science are found without jobs. This is in line with Ugwuoke and Onah (2015) who reported that some Nigerian graduates and youths who ordinarily would have gained employment in some agribusiness organizations were unemployed. In some occasions, students graduate from an agricultural science programme without requisite competencies for employment (Ugwuoke and Osinem, 2014). The poor academic performance of agricultural science students in external examinations may be attributed to the influence of home. However, Obeta (2014) stated that the academic performance of the students is a joint effort of both the school authorities and that of the parents in different homes. The major aim of the study was therefore to determine the impact of home background and locality on the academic performance of secondary school students in agricultural science.

\section{Method}

The study adopted a survey research design. The study was carried out in all the secondary schools in Enugu State, Nigeria. The population was 14,750 which was made up of 624 teachers of agriculture and 14,126 students of agriculture in Enugu State. The sample was 1,616 comprising 624 teachers of agriculture and 992 students of agriculture. The entire population of the teachers of agriculture was included in the study because of the manageable size while the 992 students of agriculture were selected using surveysystem.com. Proportionate random sampling technique was used to select the student's sample from 291 secondary schools in the 17 Local Government Areas in the state. The researchers designed a questionnaire which was used to collect data. The instrument was face-validated by three experts. The internal consistency of the instrument was established using Cronbach alpha statistical method which yielded a coefficient of 0.76 . One thousand six hundred and sixteen copies of the questionnaire were administered and 1,422 were retrieved representing a return rate of $88 \%$.

Data collected were analysed using mean to answer the research questions while t-test statistic was used to test the null hypotheses at 0.05 level of significance. An item was interpreted as agreeing when it had a mean value ranging from 2.50 to 3.49 and interpreted as disagreeing with a mean value range of 1.50 - 2.49. Similarly, a null hypothesis was accepted when the t-calculated value was less than the $t$ critical value and rejected when the t-calculated value was greater than the $t$-critical value.

\section{Results and Discussion}

Result of the impact of home background on the students' academic performance in Agriculture in secondary schools is presented in the table below. 
Table 1: Mean and t-test Analysis of the Responses of Students and Teachers of Agricultural Science on the Impact of Home Background on the Students' Academic Performance in Agriculture in Secondary Schools

\begin{tabular}{|c|c|c|c|c|c|c|c|c|c|c|c|c|}
\hline & & & & & & $\mathbf{N} 1=8$ & & & $J 2=56$ & & & \\
\hline S/N & $\begin{array}{l}\text { Item } \\
\text { statements }\end{array}$ & & & $\begin{array}{l}\text { Agric } \\
\text { Scien }\end{array}$ & $\begin{array}{l}\text { ltural } \\
\text { e Stud }\end{array}$ & ents & $\begin{array}{l}\text { Agric } \\
\text { Scien }\end{array}$ & $\begin{array}{l}\text { cltural } \\
\text { ce Tea }\end{array}$ & ers & t-cal & t-tab & Rem \\
\hline & & $\bar{X}_{G}$ & Dec & $\bar{X}_{1}$ & SD $_{1}$ & $\mathrm{SD}_{1}^{2}$ & $\overline{\mathrm{X}}_{2}$ & $\mathbf{S D}_{2}$ & $\mathrm{SD}_{2}{ }^{2}$ & & & \\
\hline 1 & $\begin{array}{l}\text { The home a } \\
\text { child comes } \\
\text { from } \\
\text { greatly } \\
\text { affects his } \\
\text { academic } \\
\text { performanc } \\
\text { e }\end{array}$ & 2.96 & $A$ & 3.15 & 0.66 & 0.44 & 2.77 & 1.04 & 1.08 & 1.94 & 1.96 & NS \\
\hline 2 & $\begin{array}{l}\text { A student } \\
\text { from rich } \\
\text { home } \\
\text { performs } \\
\text { better }\end{array}$ & 2.98 & A & 3.15 & 0.79 & 0.62 & 2.80 & 1.10 & 1.21 & 1.68 & 1.96 & NS \\
\hline 3 & $\begin{array}{l}\text { Parents } \\
\text { poverty } \\
\text { affects } \\
\text { students' } \\
\text { academic } \\
\text { performanc } \\
\text { e }\end{array}$ & 3.11 & A & 3.15 & 0.82 & 0.67 & 3.07 & 0.78 & 0.61 & 0.52 & 1.96 & NS \\
\hline 4 & $\begin{array}{l}\text { Some } \\
\text { parents } \\
\text { engage } \\
\text { their } \\
\text { children in } \\
\text { rigorous } \\
\text { work after } \\
\text { school }\end{array}$ & 2.98 & A & 3.10 & 0.80 & 0.64 & 2.85 & 0.94 & 0.88 & 1.27 & 1.96 & NS \\
\hline 5 & $\begin{array}{l}\text { Some } \\
\text { students } \\
\text { stay away } \\
\text { from school } \\
\text { frequently } \\
\text { due to the } \\
\text { inability of } \\
\text { their } \\
\text { parents to } \\
\text { meet their } \\
\text { school } \\
\text { needs }\end{array}$ & 2.98 & A & 3.15 & 0.74 & 0.55 & 2.80 & 0.96 & 0.92 & 1.91 & 1.96 & NS \\
\hline 6 & $\begin{array}{l}\text { Some } \\
\text { parents } \\
\text { send their } \\
\text { children to } \\
\text { hawk } \\
\text { during the } \\
\text { school } \\
\text { hours }\end{array}$ & 3.03 & A & 3.02 & 0.78 & 0.61 & 3.03 & 0.93 & 0.86 & -0.06 & 1.96 & NS \\
\hline 7 & $\begin{array}{l}\text { Educated } \\
\text { parents } \\
\text { teach their }\end{array}$ & 3.04 & A & 3.18 & 0.72 & 0.52 & 2.89 & 0.97 & 0.94 & 1.57 & 1.96 & NS \\
\hline
\end{tabular}




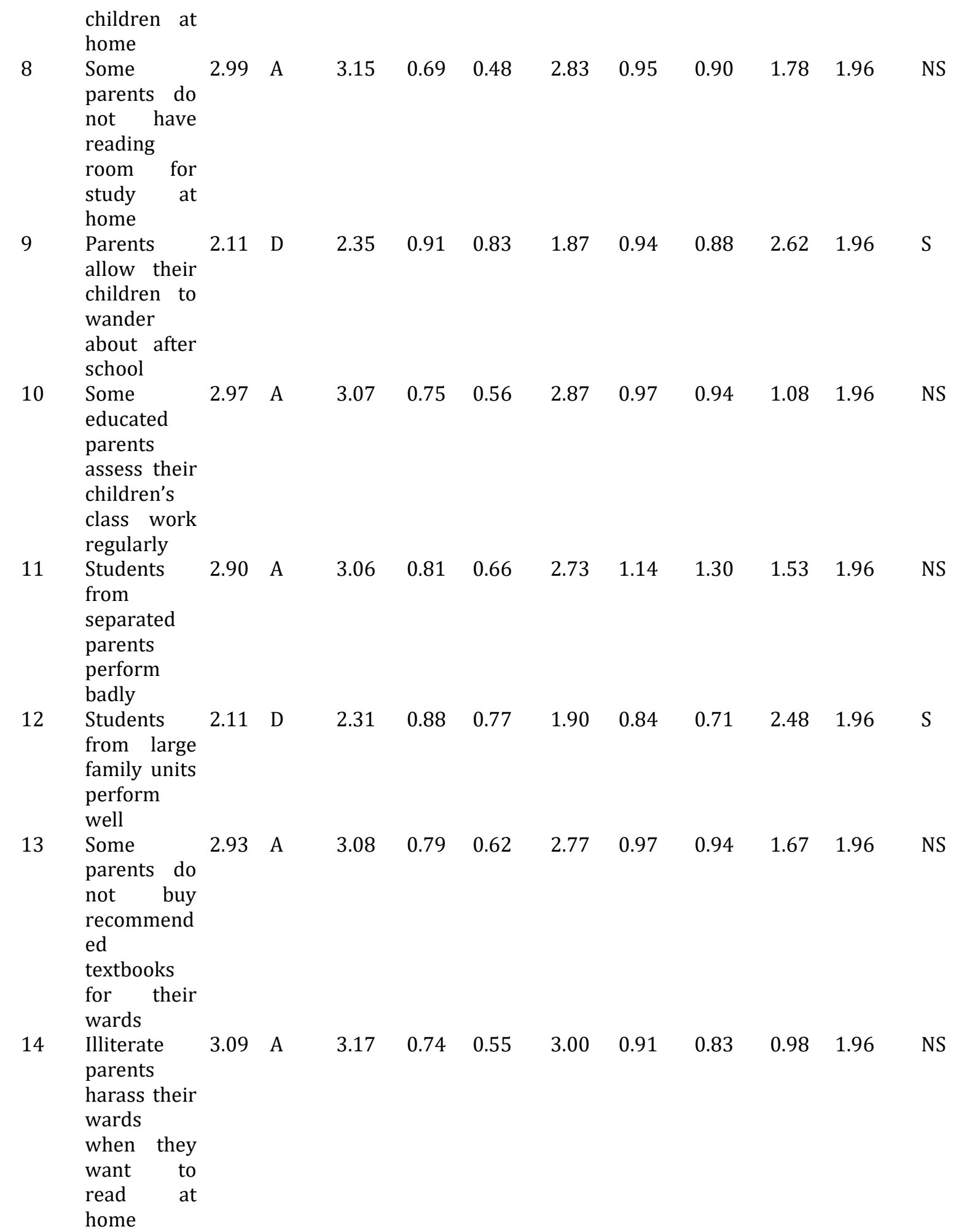

Average t-cal

$1.51 \quad 1.96 \quad$ NS

Key: NS- Not Significant; $S=$ Significant; $t$-cal $=$ calculated $t$-value; $t$-tab $=t$-table; Dec $=$ Decision; Rem $=$ Remark; $\overline{\mathrm{X}}_{G=\text { Grand Mean; }} \overline{\mathrm{X}}_{1=\text { mean responses of students; }} \overline{\mathrm{X}}_{2}=$ mean responses of teachers; $S D 1=$ standard deviation responses of students; $S D 2=$ standard deviation responses of teachers; $S D^{2}=$ standard deviation squared, $A=$ Agree; $D=$ Disagree; $N 1=$ Number of students; $N 2=$ Number of teachers

The result presented in Table 1 shows that students and teachers of agricultural science in secondary schools agree that the home a child comes from greatly affects his academic performance (2.96), a student from rich home performs better (2.98), parents' poverty affects students' academic 
performance (3.11), some parents engage their children in rigorous work after school (2.98), some students stay away from school frequently due to the inability of their parents to meet their school needs (2.98), and some parents send their children to hawk during the school hours (3.03). These were similar to Egunsola (2014) who found out that the economic status of parents had a moderate correlation with but significant effect on students' academic performance. A wealthy family will afford the cost of purchasing relevant educational materials for their children, would not engage their wards in rigorous work after school and hawking to meet the family needs. It was also reported that unconducive home environment reduces the learning capabilities of students in agriculture (Rani and Siddiqui, 2015). Similarly, it was agreed by the respondents that educated parents teach their children at home (3.04), some parents do not have a reading room for study at home (3.04), some educated parents assess their children's class work regularly (2.97), among other findings (Table 1). The study of Hamzah and Yunus (2018) was similar to these findings by reporting a statistically significant influence between the educational background of the parents and students' academic performance. Educated parents get involved in encouraging the students to learn at home, teach and guide their wards in doing homework, guide them on how to pronounce words correctly and practise how to make correct sentences (Egunsola, 2014) thereby helping them to perform well in agricultural science.

However, students and teachers of the agricultural science in secondary schools disagree that parents allow their children to wander about after school (2.11), and students from large family units perform well (2.11) (Table 1). Large family size, according to the report of Amadi and Ani (2017) has a negative influence on the academic performance of students by the inability of parents paying adequate attention to their children, inability of parents meeting children's financial needs and absence of conducive learning environment at home. Large family size predisposes some families to the challenges of poor feeding, poor clothing, insufficient fund, improper attention to children, disciplinary problems and malnutrition (Ella et al., 2015).

Furthermore, the t-test analysis shows that the $\mathrm{t}$-calculated value of 1.51 is less than the $\mathrm{t}$-critical value of 1.96. This implies that there was no statistically significant difference in the mean responses of students and teacher of agricultural science on the impact of home background on the students' academic performance in agricultural science in secondary schools (Table 1). Therefore, the null hypothesis was upheld. The respondents' agreement on the impact of home background on the academic performance of students in agriculture is in line with Doley (2018) who reported that a significant relationship existed between the home environment and academic achievement of an adolescent. Academically, favourable home environment enhances the child's motivation to achieve academic success which in turn will contribute to good performance in school (Muola, 2010).

Result of the impact of locality of the students' academic performance in agriculture in secondary schools is presented in table 2 below.

Table 2: Mean and t-test Analysis of the Students and Teachers of Agricultural Science on the Impact of Locality on the Students' Academic Performance in Agriculture in Secondary Schools

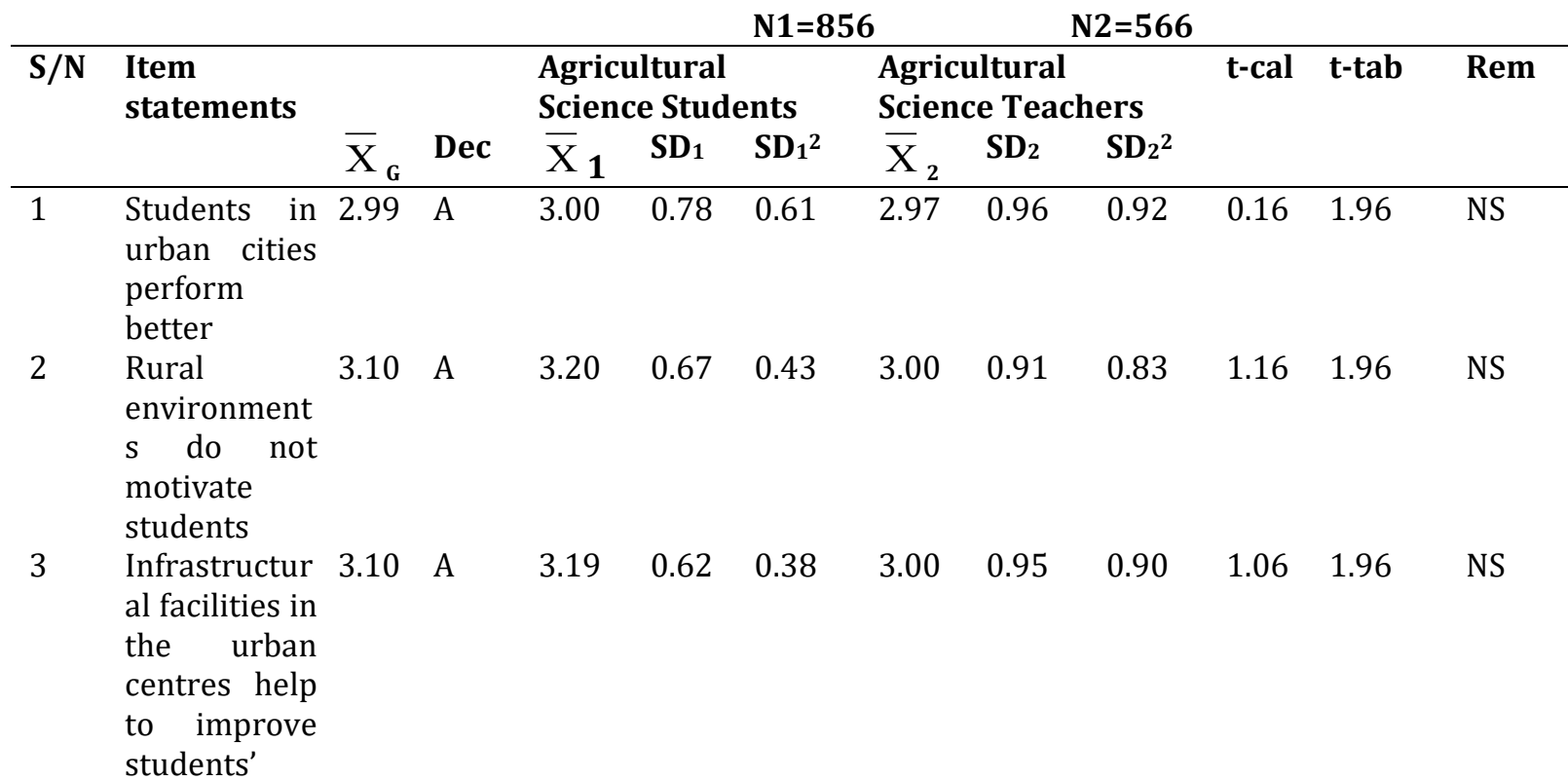


performance

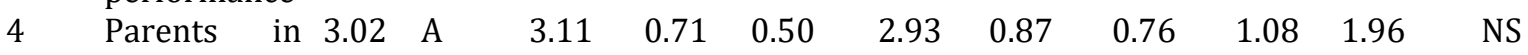

urban

environment

$\mathrm{s}$ are more

educated to

teach

children at

home

5 Rural

$3.03 \mathrm{~A}$

3.16

$0.64 \quad 0.41$

$2.90 \quad 0.99$

$\begin{array}{lll}0.98 & 1.40 \quad 1.96\end{array}$

NS

parents do

not have

enough

money to

pay for their

children's

school fees

Education is

more

competitive

in rural

areas

$7 \quad$ Population

of teachers is

high in

urban

locality

Teachers in
rural areas

are not

dedicated to

teach

9 Some

$3.06 \quad A$

3.22

$0.67 \quad 0.45$

$2.90 \quad 1.09$

$1.19 \quad 1.56 \quad 1.96$

NS

teachers in

urban

centres

engage in

other

businesses

to earn

additional

money

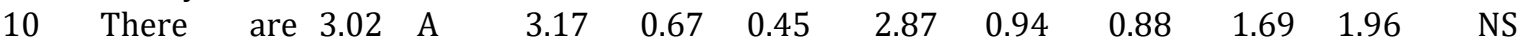

abundant

instructional

aids in urban

cities

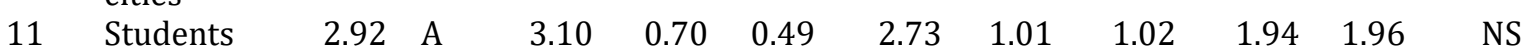

perform well

where there

are

television

sets, radio

sets and

computers

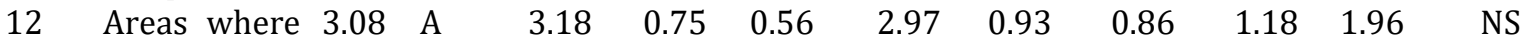

there are

functional

libraries 
improve

academic

performance

13 Presence of

laboratory in

a locality

helps to

improve

students'

academic

performance

Average t-cal

$1.50 \quad 1.96 \quad$ NS

Key: NS- Not Significant; $S=$ Significant; $t$-cal = calculated $t$-value; $t$-tab $=t$-table; Dec $=$ Decision; Rem = Remark; $\overline{\mathrm{X}}_{G=\text { Grand Mean; }} \overline{\mathrm{X}}_{1=\text { mean responses of students; }} \overline{\mathrm{X}}_{2}=$ mean responses of teachers; SD1 = standard deviation of respondents 1(students); SD2 = standard deviation of respondents 2 (teachers); $S D^{2}=$ standard deviation squared, $A=$ Agree; $D=$ Disagree; $N 1=$ Number of students; $N 2=$ Number of teachers

Results presented in Table 2 show that students and teachers of agricultural science accepted that students in urban cities perform better (2.99), rural environments do not motivate students (3.10), infrastructural facilities in urban centres help to improve students' academic performance (3.10), parents in urban environments are more educated to teach their children at home (3.02), and rural parents do not have enough money for their children's school fees (3.03). Similarly, the respondents accepted that the population of teachers is high in urban cities (3.07), some teachers in urban cities engage in other businesses to earn additional money (3.06), students perform well where there are television sets, radio sets and computers (2.92), and that areas, where there are functional libraries (3.08) and laboratories (3.10) improve students' performance (Table 2). The results are in harmony with Opoku-Asare and Siaw (2015) who found out that majority of the Basic Education Certificate Examination (BECE) high achievers in Kumasi, Ghana came from the urban schools whereas average and weak achievers came from rural schools. The locality was also found to be significant in the academic achievement of students in India as it was shown that ruralness may affect academic achievement (Sharma, 2016). It was equally found out that students in urban centres significantly perform better their rural counterparts in English language, Mathematics, Biology and Chemistry in secondary schools (Onoyase, 2015). The higher academic achievement of students in urban areas may be attributed to the functional libraries, laboratories, computers, and other teaching and learning facilities in schools. Schools in urban areas were found to have more facilities for teaching and learning of Biology, and there was a greater concentration of human resources in urban areas than those in rural areas as a result of more infrastructure (Umar, 2017).

However, students and teachers of agricultural science in secondary schools disagree that education is more competitive in rural areas (1.71) and that teachers in rural areas are not dedicated (1.71) (Table 2). This is in line with Moulton (2001) who reported that rural children, more than urban children, are required by their parents to supply labour on the farm and in the home. The spirit of competition in education is affected when rural environment did not permit seriousness among the students. Many children in rural areas receive a poor-quality education because of poor teaching and learning environment, inadequately qualified teachers and, lack of regular supervision of schools (Haruna and Liman, 2015). Education in rural areas is more stressful, less competitive and non-motivational.

Consequently, the t-test analysis shows that the $t$-calculated value of 1.50 is less than the $t$-table value of 1.96. This implies that there is no statistically significant difference in the mean responses of students and teachers of agricultural science on the impact of locality on students' academic performance in agriculture in secondary schools (Table 2). Therefore, the null hypothesis is accepted. The result was in support of Yusuf and Adigun (2010) who found out that school location did not significantly influence students' academic performance. Similarly, Alordiah et al., (2015) found out that no significant difference in the academic achievement of students' in mathematics existed with respect to school location. Classroom teachers that teach agricultural science in urban and rural schools have the same educational qualifications. However, result is in contrast with Nworgu et al., (2013) who found out that the rural students who recorded a mean score of 4.49 with a standard deviation of 1.56 demonstrated a higher conceptual understanding of force and motion than the urban students who had a mean score of 4.34 and a standard deviation of 1.58. A significant difference was equally reported in students' academic performance in the English language on the base of urban and rural school locations (Ellah and Ita, 2017). Similarly, there was a significant difference between the academic achievements of students in rural and 
urban secondary schools as measured by senior school certificate examinations (Owoeye and Yara, 2011). The students in urban areas enjoy favourable school environments with educational facilities that promote learning.

\section{Conclusions and Suggestions}

The home a student comes from plays a significant role in the academic performance of the student in agriculture. The education level of the parents, the size of the family, economic status of the family, among others, help to determine the comfortability of the home for students' academic performance. Similarly, students living in the urban areas where educational facilities and plenty qualified teachers are available, tend to perform better than students in rural areas in agricultural science. The findings provide insights to the parents to make the homes conducive to learning and also to provide the necessary environment that would promote their children's academic performance in agriculture.

\section{Refferences}

Alordiah, C.O., Akpadaka, G. \& Oviogbodu, C.O. (2015). The influence of gender, school location and socioeconomic status of students' academic achievement in Mathematics. Journal of Education and Practice, 6(17) 130-136

Amadi, E.C. \& Ani, C.N. (2017). Effects of home background and educational development of Secondary School students in Ebonyi State: A case study of Onicha L.G.A. International Journal of Innovative Social \& Science Education Research, 5(4) 46-49

Bani, S. \& Siddiqui, M.A. (2015). A study of the home environment, academic achievement and teaching aptitude on training success of pre-service elementary teachers of India. Journal of Education and Practice, 6(28) 91-96

Doley, L. (2018). The impact of home environment factors on the academic achievement of adolescents. Journal of Arts, Science and Commerce, 4(1) 137-147 http://dx.doi.org/10.18843/rwjasc/v9i1/17

Dzever, L.T. (2015). The impact of home environment factors on the academic performance of senior secondary school students in Garki Area District, Abuja-Nigeria. Bulgarian Journal of Science and Education Policy, 9(1) 66-92

Egbule, P.E. (2002). Fundamentals and Practice of Agricultural science. Owerri: Totan Publishers Ltd

Egunsola, A.O.E. (2014). Influence of home environment on the academic performance of secondary school students in agricultural science in Adamawa State, Nigeria. IOSR Journal of Research \& Method in Education, 4(4) 46-53

Ella, R.E., Odok, A.O. \& Ella, G.E. (2015). Influence of Family Size and Family Type on Academic Performance of Students in Government in Calabar Municipality, Cross River State, Nigeria. International Journal of Humanities Social Sciences and Education, 2(11)108-114

Ellah, K.E. \& Ita, P.M. (2017). The correlational relationship between school location and students' academic performance in the English language in Nigerian Secondary Schools. International Journal of Scientific and Research Publications, 7(9) 381-384

Federal Republic of Nigeria (2014). National Policy on Education. Lagos: Nigerian Educational Research and Development Council

Hamzah, M.I. \& Yunus, A. (2018). Influence of parental background of secondary school students' academic performance in Islamic studies in Nigeria. International Journal of Academic Research in Business and Social Studies. 8(1) 314-325 
Haruna, M.J. \& Liman, B.M. (2015). Challenges facing educating Nigerian child in rural areas: Implications for national development. Proceeding of the 3rd Global Summit on Education, Kuala Lumpur, Malaysia.

https://worldconferences.net/proceedings/gse2015/paper\%20gse15/G\%20088\%20CHALLENGE S\%20FACING\%20EDUCATING\%20NIGERIAN\%20CHILD\%20IN\%20RURAL\%20AREAS\%20IMPLIC ATIONS\%20FOR\%20NATIONAL\%20DEVELOPMENT\%20-\%20M.\%20J.\%20HARUNA.pdf

Kakumbi, Z., Samuel, E.B. \& Mulendema, P.J. (2016). Pupil home background characteristics and academic performance in senior secondary schools: A case study of selected secondary schools in Kitwe District, Zambia. Journal of Education and Practice, 7(22) 19-25

Mhiliwa, J.A. (2015). The effect of school location on learner's academic performance: A case of community secondary schools in Makamboka Town Council, Njombe. A Master's Degree Dissertation, University of Tanzania http://repository.out.ac.tz/1296/1/Dissertation_-_Joseph_A._Mhiliwa.pdf

Muola, J.M. (2010). A study of the relationship between academic achievement motivation and home environment among standard eight pupils. Educational Research and Reviews, 5(5) 213-217

Moulton, J. (2001). Improving education in rural areas: Guidance for rural development specialists. http://citeseerx.ist.psu.edu/viewdoc/download?doi=10.1.1.197.9341\&rep=rep1\&type=pdf

Nworgu, B.G., Ugwuanyi, C.S. \& Nworgu, L.N. (2013). School location and gender as factors in senior secondary school students' conceptual understanding of force and motion. International Journal of Educational Research and Technology, 4(4) 71-76

Obeta, A.O. (2014). Home environment factors affecting student's performance in Abia State, Nigeria. Jelgava 7: 141-149 http://llufb.llu.lv/conference/REEP/2014/Latvia-Univ-Agricult-REEP2014proceedings-141-149.pdf

Olamiju, I.O. and Olujimi, J. (2011). Regional analysis of locations of public educational facilities in Nigeria: The Akure region experience. Journal of Geography and Regional Planning, 4(7) 428-442

Onoyase, A. (2015). Academic performance among students in urban, semi-rural and rural secondary schools counselling implications. Developing Country Studies, 5(19) 122-126

Opoku-Asare, N.A.A. \& Siaw, A.O. (2015). The rural-urban disparity in students' academic performance in Visual Arts education: Evidence from six senior high schools in Kumasi, Ghana. Sage Open, 1-14

Osuafor, A. \& Okonkwo, I. (2013). Influence of family background on the academic achievement of secondary school Biology students in Anambra State. African Research Review, 7(3) 156-167 http://dx.doi.org/10.4314/afrrev.v7i3.12

Owoeye, J.S. \& Yara, P.O. (2011). School location and academic achievement of secondary school in Ekiti State, Nigeria. Asian Social Science, 7(5) 170-175

Sharma, G. (2016). Locale and sex as determinants of academic performance. International Journal of Information and Research and Review, 3(8) 2691-2694

Ugwuoke, C.U \& Onah, B.A. (2015). Skills required by agricultural education students of colleges of education for employment in the computerized office of agribusiness organizations. Journal of Education and Practice, 6(29) 84-91

Ugwuoke, C.U. \& Osinem, E.C. (2014). Competencies in cane rat production for the training of NCE agricultural education students in Nsukka agricultural zone of Enugu state, Nigeria for wealth generation after graduation. Journal of Agriculture and Biodiversity Research, 3(2) 20-26 
Umar, O.J. (2017). A comparative study of facilities and student performances in Biology in urban and rural schools: A case study of Adavi Local Government Area of Kogi State. International Journal of Education and Evaluation, 3(6) 1-6

Yusuf, M.A. \& Adigun, J.T. (2010). The influence of school sex, location and type on students' academic performance. Int J Edu Sci, 2(2) 81-85. 